\title{
Yerel Halkın Serbest Zaman Değerlendirme Alışkanlıkları: Safranbolu Örneği
}

Nuray Türkera* ${ }^{*}$, Hanife Ölçerb ${ }^{\text {, Arzuhan Aydın }}$

aKarabük Üniversitesi, Turizm Fakültesi, Karabük.

b,cKarabük Üniversitesi, Sosyal Bilimler Enstitüsü Turizm İşletmeciliği ABD, Karabük.

$\ddot{O} z$

İnsanların yaşamlarında önemli bir yer tutan serbest (ya da boş) zaman, kişinin çalışma ve kişisel bakım gibi zorunlu faaliyetleri dışında kalan zamanı eğlenceli, dinlendirici bir uğraşı ile geçirdiğ i zamanı ifade etmektedir. Bu çalışmada Safranbolu halkının serbest zamanı değerlendirme etkinlikleri incelenmiştir. Bu amaçla 429 kişiye anket uygulanmış ve çalışmada Safranbolu halkının serbest zamanların aile ile TV seyrederek, dinlenerek, gezmeye giderek, müzik dinleyerek genelde pasif aktivitelerle geçirdikleri, serbest zamanın değerlendirilmesinde ev içi faaliyetlerin önemli yer tuttuğu bulgularına ulaşılmıştır. Ayrıca halkın serbest zamanlarını ă̆ırlıklı olarak arkadaşlarıyla geçirdikleri ancak serbest zaman faaliyetleri için fazla zaman ayırmadıkları saptanmiştır.

Anahtar Kelimeler: Serbest zaman, Serbest zaman alıskanlıkları, Rekreasyon, Safranbolu.

\section{Leisure Time Habits of Residents: A Case Study on Safranbolu}

\section{Abstract}

Leisure time that holds an important place in people's lives expresses time which stay out of compulsory activities such as work and personal care that they spend with enjoyable and relaxing activities. In this study leisure time activities of residents in Safranbolu are examined. Survey was conducted with 429 residents and it is determined that residents of Safranbolu spend their leisure time by passive activities such as watching TV with family, resting, jaunting, listening to music. Findings show that residents spend their leisure time at home. Besides residents predominantly spend their time with friends and they do not allocate much time for leisure activities.

Keywords: Leisure time, Leisure time habits, Recreation, Safranbolu.

\section{Gíriş}

Sanayileşme ile birlikte zaman kavramında da yeni yaklaşımlar ortaya çıkmıştır. Modern döneme ait bir kavram olan çalışma dışı zaman anlayışı, günlük zorunlu programlamaların dışında, insanların diledikleri gibi değerlendirebilecekleri bir zaman dilimini ifade etmektedir. Sanayileşmedeki gelişmelere paralel olarak ortaya çıkan teknolojik gelişmeler, yaşamın bu gelişmelere bağlı olarak kolaylaşması, gelişmelerin sağladığı hız ve konfor serbest zamanın artmasına olanak sağlamıştır. Bu zaman diliminde birey, dinlendirici, eğlendirici, zevk verici faaliyetlere katılarak ruhen ve bedenen canlılık kazanmaktadır. Serbest zaman değerlendirme etkinlikleri kapsamında yapılan en çekici etkinlikler; sinemaya, tiyatroya gitmek, spor gösterilerini izlemek, televizyon seyretmek, kitap okumak ve müzik dinlemektir. Serbest zamanın aktif olarak değerlendirildiği etkinlikler ise; seyahat etmek, kamp kurmak, spor yapmak vb.'dir.

* Yazışma Adresi.Email.nturker@karabuk.edu.tr 
Bu çalışmada Safranbolu' da yaşayan yerel halkın serbest zaman değerlendirme alışkanlıklarının belirlenmesi amaçlanmaktadır. Çalışma alanı olan Safranbolu tarihi geçmişi nedeniyle önemli bir kültür turizmi alanıdır. 1994 yılında UNESCO Dünya Miras Kenti olarak ilan edilmiştir. 1990'lı yıllarda gelişmeye başlayan turizm endüstrisi şehirdeki rekreatif etkinliklerin çeşitlenmesine katkı sağlamış, şehirde yapılabilecek serbest zaman etkinlikleri artmıştır. Bu bağlamda çeşitli zamanlarda düzenlenen kültürel aktiviteler, konserler, film festivalleri, mutfak şenlikleri, kırsal alanda organize edilen doğa yürüyüşleri, ziyarete açllan müzeler, vakit geçirilebilecek eğlence ve yiyecek-içecek mekanları ile turistik çekiciliği olan mekanlar halkın katılabileceği serbest zaman etkinliklerini arttırmaktadır.

Literatürde halkın serbest zaman faaliyetlerinin belirlenmesine yönelik çalışmaların az olması bu araştırmanın önemini arttırmaktadır. Çalışma Safranbolu halkının katıldığı serbest zaman etkinliklerinin belirlenmesi açısından literatüre katkı sağlayacaktır.

\section{LITERATÜR}

Zaman, durdurulamayan, geriye döndürülemeyen ve değiştirilemeyen bir olgudur. Bu nedenle zamanın etkili ve verimli kullanılması insan yaşamında büyük önem taşımaktadır (Dağlı, 2013; Göral, 2013). İnsanlar zamanlarının büyük bir kısmını kişisel işleri için harcamaktadır. Geriye kalan zamanın bir bölümü ise kazanç elde etmek için işe, bir kısmı aileye, bir kısmı da eğlence ya da hobi için ayrılmaktadır (Pala, 2012: 12).

Serbest zaman bireyin yaşamını devam ettirebilmesi için çalışma ve zorunlu ihtiyaçlarını karşılama zamanı dışında kalan ve bireysel tercihlerine ayırabileceği zamanı ifade etmektedir. Sabbağ ve Aksoy'a (2011) göre, serbest zaman günlük hayatın uyku, dinlenme ve çalışma zamanı dışında kalan, bireyin istediği gibi kullanabileceği zaman dilimidir. Serbest zaman kavramı İngilizcede Leisure anlamına gelmektedir (Köybaşı, 2006).

Serbest zaman kavramı, uluslararası literatürde bir etkinlik olarak değerlendirilmektedir. Serbest zaman etkinliği, kişinin mesleki, ailevi ve toplumsal görevlerini yerine getirdikten sonra dinlenme, eğlenme, bilgi ya da becerilerini geliştirme, toplum yaşamına katılma (Altunay, 2015) amacıyla değerlendirebileceği zamanı ifade etmektedir.

Serbest zaman olgusu ile ilgili olarak rekreasyon kavramından da bahsetmek gerekir. Rekreasyon, bireylerin günlük rutin faaliyetler dışındaki serbest zamanlarını istedikleri şekilde değerlendirdikleri aktivitelerdir (Yaşar, 2015). Latince yenilenme, yeniden yaratılma veya yeniden yapılanma anlamina gelen "recreatio" kelimesinden gelen rekreasyon, insanların serbest zamanlarında yaptıkları zevk verici etkinlikleri ifade etmektedir (Öksüz, 2012; Metin, Kesici ve Kodaş, 2013).

Çalışma yaşamı ve diğer etkinliklerin birbirinin tekrarı olan sıkıcı ve monoton faaliyetlerden oluşması günlük yaşamda rekreasyon faaliyetlerini insan yaşamının önemli bir parçası haline getirmiştir (Özşaker, 2012). Çalışma yaşamı dışında kalan bu 
sürenin hoş bir biçimde değerlendirilmesi amacıyla ortaya çıkan rekreasyon faaliyetleri kapsamında sanatsal etkinlikler, spor aktiviteleri, eğitsel faaliyetler ve kişisel hobileri geliştirecek pek çok faaliyet yer almaktadır (Şentürk, 2012).

Çalışanların serbest zamanlarını etkin bir şekilde değerlendirmeleri, kişilerin çalışma hayatının neden olduğu stres ve yorgunluktan kurtulmaları, sosyal ve kişisel yaşamda daha mutlu ve başarılı olmaları açısından önemlidir. Çalışan bir insanın başarılı olabilmesi için, iş yaşamında olduğu kadar sosyal hayatta da başarılı olması, çeşitli hobilere sahip olması ve özel hayatına yeterli zaman ayırabilmesi gerekir (Sabbağ ve Aksoy, 2011: 11). Ergin'e göre (1974:29-35) serbest zaman etkinliklerine katılma bireyin;

- Ruh sağlığının gelişmesini ve düzenlenmesini sağlar,

- Yeteneklerin geliştirilmesine yardım eder,

- Fiziki mutluluk sağlar,

- Yaşamı geliştirme amacı taşır,

- Çalışmayı verimli kılar ve verimliliği arttırır,

- Yeni bilgi ve beceriler kazandırır,

- Üretimin artmasına katkıda bulunur.

Rekreatif faaliyetler hem kişisel hem de toplumsal olarak çeşitli yararlar sağlamaktadır. Fiziksel sağlığı geliştirmesi, ruh sağlı̆̆ını iyileştirilmesi, insanın sosyalleşmesini sağlaması, yaratıcığı arttırması, kişisel beceri ve yeteneği geliştirmesi, çalışma başarısı ve iş verimini etkilemesi, ekonomik hareketlilik sağlaması, insanı mutlu etmesi ve entelektüel yaşamı geliştirmesi rekreatif faaliyetlerin kişi üzerinde yarattığı en önemli etkilerdir. Ayrıca rekreasyon faaliyetleri, kişiye özgüven kazandırmakta, kendini gerçekleştirmesine katkıda bulunmakta ve kişinin saygınlığını arttırmaktadır (Kara, İzci ve Murathan, 2011). Demokratik bir toplum oluşturulması, toplumsal dayanışma ve bütünleşmeye katkı sağlaması ise rekreasyonun toplumsal yararlarıdır (Sarıbaş, 2010: 27). Bu kapsamda serbest zaman değerlendirme; yüzme, futbol, seyahat, sinemaya gitme gibi çeşitli faaliyetlerle gerçekleştirilir ve bu faaliyetlerin tümü "rekreasyon" olarak isimlendirilir (Yetim, 2014: 6).

Çalışma hayatının dışında, eğlence ile geçirilen bir “serbest zaman” olgusunun tarihsel ve toplumsal geçmişi 19. yüzyıla kadar uzanmaktadır. Bilim ve teknolojideki gelişmeler, hızlı nüfus artışlarıyla ortaya çıkan demografik farklılıklar, kentleşme oranının artması, çalışma süresini kısaltan teknolojik gelişmeler ve üretim anlayışları, “serbest zaman" etkinliklerinin artmasına olanak sağlamıştır (Şentürk, 2012).

Serbest zaman faaliyetleri bireylerin kendi tatminleri için seçtiği etkinliklerdir. Bu faaliyetler sayesinde birey, günlük yaşantısının ötesinde farklı bir şeyler yapma, yeni beceriler elde etme, kişiliğinin diğer yönünü ortaya çıkarma ve yeni insanlarla tanışma fırsatı bulmaktadır (Özgören, 2007). Bodur'a (1988) göre zamanını en iyi biçimde değerlendirilmesi, iş, öğrenim, dinlenme, eğlenme faaliyetleri arasında denge kurulması insanın kişiliğinin gelişmesinde önemli rol oynamaktadır. Bu faaliyetler arasında denge kurulamaması kişide birtakım ruhsal dengesizliklere sebep olabilir. 
İnsanlar, serbest zamanlarında; bulundukların ortamdan uzaklaşmak, dinlenmek, hava değişimi sağlamak, gezmek-görmek, sağlıklı olmak, insanlarla vakit geçirmek, heyecan duymak, farklı ortamlarda bulunmak gibi pek çok amaçla, ev dışında veya ev içinde, açık veya kapalı alanlarda, pasif ya da aktif şekillerde, kent içinde veya kırsal alanlarda etkinliklere katılmaktadırlar.

Serbest zamanları değerlendirme faaliyetleri içeriklerine ve yapıldığı mekanlara göre farklılık göstermektedir. Bu etkinliklerden hangisinin tercih edileceği kişinin ruhsal ve fiziksel yapısına, cinsiyetine, eğitimine, sahip olduğu olanaklara ve yeteneklerine bağlı olarak değişmektedir (Köybaşı, 2006). Serbest zamanla kavramıyla ilgili yapılan araştırmalarda birçok rekreasyon faaliyeti türü tanımlanmış ve bu faaliyetler farklı şekillerde sınıflanmıştır (Akyıldız, 2013: 23). Abadan (1961:23) serbest zaman faaliyetlerini sert ve yumuşak serbest zaman etkinlikleri olmak üzere iki grupta toplamaktadır. Bu gruplamada bireyin etkin katılımı esas alınmıştır. Sert etkinlikler; kitap okumak, spor yapmak, müzik icra etmek, el işi yapmak v.b., Yumuşak etkinlikler; dans, sinemaya gitmek, gençlik gruplarına üye olmak, radyo dinlemek vb. dir.

Serbest zaman etkinlikleri aktif (spor yapmak, yürümek) ya da pasif (kitap okumak, televizyon seyretmek vb.), toplumun ya da bireyin yararına olan, tek başına (kitap okumak, müzik dinlemek v.b.) ya da grupla (top oynamak v.b.) yapılabilen, günün herhangi bir saatinde ya da belirli saatlerde düzenli olarak yapılan, bir araç kullanımını gerektiren ya da herhangi bir araç kullanılmaksızın yapılabilen etkinliklerdir. Bu tür etkinliklere katılmada bireyin gönüllü olması, zevk alması, ekonomik bir yarar amacı gütmemesi, bağımsız olarak seçmesi ve bireye bağımsızlık duygusu kazandırması gibi hususlar beklenir. Serbest zaman etkinliklerinin (1) dinlenme, (2) eğlenme ve (3) ilerleme olmak üzere üç tür işlevi yerine getirdiği söylenebilir (Bayer, 1974:49).

Literatürde serbest zaman davranışına yönelik az sayıda çalışma bulunmaktadır. Bu çalışmalardan elde edilen bulgular incelendiğinde farklı sonuçlara ulaşılmıştır. Yapılan araştırmalar, bireylerin serbest zaman alışkanlıklarının yer, zaman, cinsiyet, gelir durumuna göre farklılık gösterdiğini ortaya koymaktadır. Örneğin, Kurar ve Baltacı (2014) Alanya'da yaptıkları çalışmada Alanya halkının rekreasyonel deneyimleri ve serbest zaman değerlendirme alışkanlıklarını ortaya koymaya çalışmışlar ve serbest zaman faaliyetlerinin genel olarak piknik ve arkadaş ziyaretlerinden oluştuğunu saptamışlardır. Ayrıca katılımcıların çoğunluğu erkektir ve gelir miktarı orta düzeydedir.

Yeniçeri ve arkadaşlarının (2002), Muğla il merkezindeki memurların serbest zaman değerlendirme eğilimlerinin belirlenmesi üzerine yaptıkları bir araştırmada, katılımcıların genelde serbest zamanlarını evde, açık kırsal alanlarda gerçekleştirdikleri etkinliklerle değerlendirdikleri, bunun yanı sıra spor tesisleri ve kahvehanelerde serbest zaman geçirenlerin tamamına yakınının erkekler olduğu sonucuna ulaşılmıştır.

Kara ve arkadaşlarının (2011) ilköğretimde görev yapan beden eğitimi öğretmenlerinin serbest zamanlarını değerlendirme alışkanlıklarının belirlenmesi 
üzerine yaptıkları çalışmada, öğretmenlerin serbest zamanlarını değerlendirme alışkanlıklarında cinsiyetler açısından anlamlı farklılıklar olduğu sonucuna varmışlardır.

Arslan'ın (2014) üniversite öğrencilerinin serbest zaman değerlendirme tercihlerini belirlemek amacıyla yaptıkları çalışmada öğrencilerin serbest zamanlarını genellikle amaçlı olarak gerçekleştirmedikleri, zaman geçirmeye yönelik faaliyetleri daha çok tercih ettikleri belirlenmiştir. Ayrıca çalışmada serbest zaman faaliyetleri ile yaş arasında bir ilişki olduğu, katılımcıların yaşları arttıkça amaçlı faaliyetlere katılma oranının arttığı saptanmıştır.

Demirel ve Harmandar'ın (2009) üniversite öğrencilerinin rekreasyonel etkinliklere katılımlarındaki engellerin belirlenmesine yönelik olarak yaptığı çalışmaya göre, katılımcıların serbest zaman aktivitelerine katılmalarındaki en büyük engel sosyal ortam ve bilgi eksikliği sonrasında ise tesis / hizmet / ulaşım yetersizliği ile bireyin psikolojik durumudur.

\section{METODOLOJí}

Araştırmanın temel amacı Safranbolu halkının katıldığı serbest zaman etkinliklerinin belirlenmesidir. Bu amaçla ilgili literatür (Arslan, 2014; Bodur,1988; Dağl1, 2013; Gülbahçe, 1996; Kurar ve Baltac1, 2014; Öksüz, 2012; Özgören, 2007; Pala, 2012; Sabbağ ve Aksoy, 2011; Şentürk, 2012; Yazıcıŏlu, 2010; Yeniçeri ve diğerleri, 2002) incelenerek araştırmacılar tarafından yapısal bir anket formu oluşturulmuştur. Örneklem gelişigüzel örnekleme yöntemiyle seçilmiştir. Anketler Ekim-Kasım 2015 tarihleri arasında Safranbolu merkezde ikamet eden toplam 650 kişiye uygulanmış ancak 429 anket doldurulmuş olarak geri dönmüştür.

Anket toplam 39 sorudan oluşmaktadır. Anketin ilk bölümü katılımcıların serbest zaman alışkanlıklarına ilişkin bilgileri elde etmeye yönelik sorulardan oluşmaktadır. İkinci kısımda katılımcıların katıldıkları serbest zaman belirlenmeye çalışılmıştır. Katılımcıların serbest zaman faaliyetlerine katılma sıklığını 5'li Likert ölçeğinde (1: Hiç, 2: Nadiren, 3: Bazen, 4: Sık sık, 5: Her zaman) değerlendirmeleri istenmiştir. Üçüncü bölüm ise katılımcıların demografik özellikleri ile ilgili sorulardan oluşmaktadır.

Elde edilen verilerin analizinde Sosyal Bilimler için istatistik paket programı kullanılmıştır. Çalışmada elde edilen veriler yüzde frekans, ortalama, Mann-Whitney U Testi, Kruskal-Wallis H Testleri kullanılarak analiz edilmiştir.

\section{BULGULAR}

\section{Katılımcıların Demografik Profili}

Halkın serbest zamanlarını değerlendirme alışkanlıkları, her şeyden önce onların bazı kişisel özellikleriyle yakıdan ilgilidir. Katılımcıların cinsiyet, medeni durum, yaş, meslek, eğitim durumu, ikamet süresi ve gelire ilişkin demografik özellikleri Tablo 1'de verilmiştir. 
Tablo 1. Katılımcıların Demografik ve Sosyo-Ekonomik Özellikleri

\begin{tabular}{|c|c|c|c|c|c|}
\hline Cinsiyet & Frekans (n) & $\%$ & Yaş & Frekans (n) & $\%$ \\
\hline Kadın & 237 & 55,2 & $25 Y_{11}$ ve Alt1 & 96 & 22,4 \\
\hline Erkek & 192 & 44,8 & 26-30 Yil & 70 & 16,3 \\
\hline Medeni Durum & Frekans (n) & $\%$ & 31-35 Yil & 77 & 17,9 \\
\hline Evli & 263 & 61,3 & $36-40 Y_{11}$ & 59 & 13,8 \\
\hline Bekâr & 166 & 38,7 & 41-45 $Y_{11}$ & 50 & 11,7 \\
\hline İkamet Süresi & Frekans (n) & $\%$ & 46 Yil ve Üstü & 77 & 17,9 \\
\hline 1 yıldan az & 28 & 6,5 & Meslek & Frekans (n) & $\%$ \\
\hline $1-5$ yıl & 83 & 19,3 & Memur & 114 & 26,6 \\
\hline 6-10 yil & 47 & 11,0 & Esnaf & 68 & 15,9 \\
\hline 11-15 yil & 60 & 14,0 & İşçi & 95 & 22,1 \\
\hline 16 yildan fazla & 211 & 49,2 & Emekli & 20 & 4,7 \\
\hline Eğitim Durumu & Frekans (n) & $\%$ & Öğrenci & 63 & 14,7 \\
\hline İlköğretim & 51 & 11,9 & Ev Hanımı & 19 & 4,4 \\
\hline Ortaöğretim & 116 & 27,0 & Profesyonel İşler & 27 & 6,3 \\
\hline Önlisans & 82 & 19,1 & Diğer & 23 & 5,4 \\
\hline Lisans & 141 & 32,9 & Gelir & \multicolumn{2}{|l|}{ Frekans (n) } \\
\hline Lisansüstü/Doktora & 39 & 9,1 & 1000 TL ve altı & 128 & 29,8 \\
\hline Toplam & 429 & 100 & $1001-2000 \mathrm{TL}$ & 127 & 29,6 \\
\hline & & & 2001-3000 TL & 88 & 20,5 \\
\hline & & & 3001-4000 TL & 39 & 9,1 \\
\hline & & & 4001 TL ve üzeri & 47 & 11,0 \\
\hline & & & Toplam & 429 & 100 \\
\hline
\end{tabular}

Tablo 1'de görüldüğü üzere 429 katılımcının büyük çoğunluğunu kadınlar $(n=238 ; \% 55,3)$ ve evli olanlar $(n=264 ; \% 61,4)$ oluşturmaktadır. Katılımcıların yaklaşık yarısı 16 yıldan uzun süredir Safranbolu'da yaşamaktadır. Katılımcıların \%32,9'u üniversite mezunudur. Bu sayıya Lisansüstü/Doktora (\%9,1)yapanlar da eklendiğinde katılımcıların \%42'sinin yüksek öğretim diplomasına sahip oldukları görülmektedir. Katılımcıların \%26,6'sı memur, \%22,2'si işçi, \%15,9'u ise esnaftır. Katılımcıların \%29,8'inin aylık geliri 1000 TL ve altında, \%29,6'sının geliri 1001-2000 TL arasında ve $\% 20,5$ 'inin geliri ise 2001-3000 TL arasındadır. Katılımcıların yaşları dikkate alındığında \%22,4'ü 25 yaş ve altında, \%17,9'u 31-35 yaş aralığında ve \% 17,9'u 46 yaş ve üzeri yaştadır.

Tablo 2. Katılımcıların Serbest Zaman Faaliyetlerine Katılmama Nedenleri

\begin{tabular}{l|c|c|c}
\hline \multicolumn{1}{c|}{ Nedenler } & $\mathbf{n}$ & $\overline{\mathbf{X}}$ & S.D. \\
\hline Hep çalışıyorum. Hiç vaktim yok & 284 & 3,302 & 1,409 \\
\hline Safranbolu'da yapılacak faaliyet yok & 285 & 3,480 & 1,246 \\
\hline Ekonomik yetersizlikler & 282 & 3,148 & 1,298 \\
\hline Faaliyetleri birlikte yapabileceğim arkadaşım yok & 282 & 3,695 & 1,281 \\
\hline $\begin{array}{l}\text { Serbest zamanı belirli faaliyetlerle değerlendirme alışkanlığım } \\
\text { yok }\end{array}$ & 281 & 3,441 & 1,324 \\
\hline
\end{tabular}


Katılımcıların serbest zaman faaliyetlerine katılmama nedenleri; faaliyetlere katılabilecekleri arkadaşlarının olmaması $(\bar{X}=3,695)$, Safranbolu'da yapılacak faaliyetlerin yetersiz olması $(\bar{X}=3,480)$ ve serbest zaman değerlendirme alışkanlığının olmamasidır $(\bar{X}=3,441)$.

Tablo 3. Serbest Zamanın Geçirildiği Alanlar

\begin{tabular}{lcc}
\hline Alanlar & Frekans (n) & \% \\
\hline Açık alanda & 231 & 53,8 \\
\hline Evde & 237 & 55,2 \\
\hline Spor tesislerinde & 52 & 12,1 \\
\hline Dernek-Kulüp gibi kuruluşlar & 23 & 5,4 \\
\hline Kahvede/Lokalde & 64 & 14,9 \\
\hline Diğer (Cami, bahçe v.b) & 16 & 3,7 \\
\hline
\end{tabular}

Katılımcıların \%55,2'si (n=331) serbest zamanlarını evde geçirmekte iken \%53,8'i $(n=331)$ ise serbest zamanını açı alanda değerlendirmektedir. Bunun yanı sıra katılımcıların \%14,9'u kahve ya da lokalde, \%12,1'i ise zamanının spor tesislerinde geçirmektedirler.

Tablo 4. Serbest Zaman Faaliyetlerine Günlük Katılma Süresi

\begin{tabular}{lcc}
\hline Süre & Frekans $(\mathbf{n})$ & $\mathbf{\%}$ \\
\hline Hiç & 98 & 22,8 \\
\hline 1 Saatten $\mathrm{Az}$ & 234 & 54,5 \\
\hline 1-2 Saat & 66 & 15,4 \\
\hline 3-4 Saat & 12 & 2,8 \\
\hline 4 Saatten Fazla & 30 & 7,0 \\
\hline
\end{tabular}

Cevaplayıcıların yarıdan fazlası $(\% 54,5)$ günde bir saatten az süre ile serbest zaman faaliyetlerine katılabildiklerini, \%22,' 8 'i ise hiç katılamadıklarını belirtmektedirler. Serbest zaman faaliyetlerine günde 1-2 saat ayırabilenlerin oranı ise $\% 15,4$ 'tür.

Tablo 5. Serbest Zaman Faaliyetlerine Katılınan Gün Sayısı (Haftalık)

\begin{tabular}{lcc}
\hline Gün & Frekans (n) & $\%$ \\
\hline Hiç & 90 & 21,0 \\
\hline 1-2 Gün & 76 & 17,7 \\
\hline 3-4 Gün & 158 & 36,8 \\
\hline 5-6 Gün & 72 & 16,8 \\
\hline 4 Her Gün & 32 & 7,5 \\
\hline
\end{tabular}

Cevaplayıcıların \%21'i serbest zaman faaliyetlerine bir haftada hiç katılmazken $\% 36,8$ 'i haftada 3-4 gün, \%17,7'si ise haftada 1-2 gün serbest zaman faaliyetlerine katılabildiklerini ifade etmişlerdir. 
Tablo 6. Serbest Zaman Faaliyetlerine Birlikte Katılınan Kişiler

\begin{tabular}{lcc}
\hline Kişiler & Frekans $(\mathbf{n})$ & $\mathbf{\%}$ \\
\hline Arkadaşlarla & 281 & 65,5 \\
\hline Eşim ve çocuklarımla & 146 & 34,0 \\
\hline Yalnız & 75 & 17,5 \\
\hline Eşimle & 40 & 9,3 \\
\hline Çocuklarımla & 29 & 6,8 \\
\hline Akrabalarımla & 38 & 8,9 \\
\hline Anne, baba ve kardeşlerimle & 59 & 13,8 \\
\hline Diğer & 14 & 3,3 \\
\hline
\end{tabular}

Tablo 6 incelendiğinde katılımcıların serbest zaman etkinliklerine farklı (bireysel ya da gruplar halinde) kişi ve gruplarla katıldıkları görülmektedir. Katılımcıların \% 65,5'i serbest zaman faaliyetlerini arkadaşlarıyla, \% 34'ü eşi ve çocuklarıyla, \% 17,5'i yalnız ve \% 13,8'i anne, baba ve kardeşleriyle geçirmektedirler Bu durumda serbest zamanın en çok birlikte değerlendirildiği kişiler arkadaşlardır.

Tablo 7. Serbest Zaman Faaliyetlerine Yönelik Bulgular

\begin{tabular}{l|c|c}
\hline \multicolumn{1}{c|}{ Tercih Edilen Serbest Zaman Etkinlikleri } & $\overline{\mathrm{X}}$ & S.D. \\
\hline Kitap, gazete ve dergi okurum & 3,051 & 1,331 \\
\hline Spor yaparım & 2,463 & 1,257 \\
\hline Balık tutarım. & 1,589 & 1,118 \\
\hline Maç izlerim & 2,603 & 1,603 \\
\hline Arkadaş, komşu ve akraba ziyaretlerine giderim & 3,086 & 1,159 \\
\hline Kahveye giderim & 1,902 & 1,321 \\
\hline Kafe ve pastaneye giderim. & 2,755 & 1,298 \\
\hline Dinlenirim. & 3,578 & 1,077 \\
\hline Alışveriş yaparım/çarşı pazar dolaşırım & 3,076 & 1,198 \\
\hline Internette vakit geçiririm. & 3,123 & 1,336 \\
\hline Bahçe işleri ile uğraşırım & 1,878 & 1,218 \\
\hline Çeşitli kurslara (bilgisayar, yab. dil,vb.) katılırım & 1,862 & 1,229 \\
\hline Müzik dinlerim & 3,331 & 1,321 \\
\hline Bara ya da birahaneye giderim & 1,554 & 1,106 \\
\hline Sinemaya, tiyatroya, konsere giderim & 2,419 & 1,198 \\
\hline Pikniğe giderim & 2,911 & 1,130 \\
\hline Gezmeye giderim & 3,524 & 1,053 \\
\hline TV seyrederim & 3,657 & 1,113 \\
\hline Ailemle vakit geçiririm & 3,813 & 1,229 \\
\hline El işi yaparım & 1,883 & 1,256 \\
\hline Dini sohbetlere katılırım & 2,228 & 1,287 \\
\hline Şehir dişına seyahate giderim & 2,466 & 1,198 \\
\hline Doğada yürüyüş yaparım & 2,538 & 1,219 \\
\hline Okey/Tavla oynarım & 2,200 & 1,360 \\
\hline Başka bir işte çalışıyorum & 1,706 & 1,301 \\
\hline
\end{tabular}


Tablo 8. Serbest Zaman Faaliyetlerine Yönelik Bulgular (Devamı)

\begin{tabular}{l|c|c}
\hline \multicolumn{1}{c|}{ Tercih Edilen Serbest Zaman Etkinlikleri } & $\bar{X}$ & S.D. \\
\hline Radyo dinlerim. & 2,324 & 1,296 \\
\hline Parka giderim & 2,356 & 1,260 \\
\hline Telefonda arkadaşlarımla konuşurum & 3,167 & 1,226 \\
\hline
\end{tabular}

Tablo 7, cevaplayıcıların serbest zamanlarında yaptıkları etkinlikleri göstermektedir. Katılımcıların ağırlıklı olarak serbest zamanlarını aile ile $(\bar{X}=3,813)$, TV seyrederek $(\bar{X}=3,657)$, dinlenerek $(\bar{X}=3,578)$, gezmeye giderek $(\bar{X}=3,524)$, müzik dinleyerek $(\bar{X}=3,331)$ geçirdikleri görülmektedir. Katılımclar serbest zamanlarını pasif olarak geçirmektedirler. Katılımcıların yaklaşık yarısı serbest zamanlarını ev içinde aile ile ya da ev içi etkinliklerle geçirmektedir. Katılımcıların en az yaptıkları serbest zaman etkinlikleri ise balık tutmak $(\bar{X}=1,589)$, bara ya da birahaneye gitmek $(\bar{X}=1,554)$ ve başka bir işte çalışmaktır $(\bar{X}=1,706)$.

Tablo 9. Katılımcıların Cinsiyetine ve Medeni Durumuna Göre Serbest Zaman Faaliyetlerinin Karşılaştırılması (Mann-Whitney U Testi)

\begin{tabular}{|c|c|c|c|c|c|c|}
\hline \multicolumn{2}{|c|}{ Değişkenler } & $\mathbf{N}$ & $\begin{array}{c}\text { Sıralama } \\
\text { Değeri } \\
\text { Ortalaması }\end{array}$ & $\begin{array}{c}\text { Siralama } \\
\text { Değerleri } \\
\text { Toplamı }\end{array}$ & $\begin{array}{c}\text { Mann- } \\
\text { Whitney U }\end{array}$ & $\mathrm{p}$ \\
\hline \multirow{2}{*}{ Cinsiyet } & Erkek & 237 & 211,49 & 50122,50 & \multirow{2}{*}{21919,500} & \multirow{2}{*}{0,514} \\
\hline & Kadın & 192 & 219,34 & 42112,50 & & \\
\hline \multirow{2}{*}{$\begin{array}{l}\text { Medeni } \\
\text { Durum }\end{array}$} & Evli & 263 & 201,82 & 53078,50 & \multirow{2}{*}{18362,000} & \multirow{2}{*}{$0,006^{*}$} \\
\hline & Bekâr & 166 & 235,89 & 39157,00 & & \\
\hline
\end{tabular}

${ }^{*} p<0,05$

Katılımcların cinsiyet ve medeni durumlarına göre serbest zaman faaliyetlerine katılmaları arasında anlamlı bir farklılık olup olmadığını belirleyebilmek amacıyla yapılan Mann-Whitney U testi sonuçları Tablo 8'de görülmektedir. Erkek ve kadınların katıldıkları serbest zaman faaliyetlerine ilişkin ifadelere verdikleri cevaplar dikkate alındığında kadın ve erkek arasında (U=21919,5;p>0,05) anlamlı bir farklılık bulunamamıştır. Bunun yanı sıra evli ve bekârların katıldıkları serbest zaman faaliyetlerine ilişkin ifadelere verdikleri cevaplar arasında $(U=18362,0 ; p<0,05)$ anlamlı bir farklılık olduğu görülmektedir. Medeni duruma ilişkin sıralama değeri ortalaması incelendiğinde evli ve bekarların katıldıkları serbest zaman faaliyetleri arasından farklılık olduğu ve bekârların serbest zaman faaliyetlerine katılma konusunda, evlilere göre daha olumlu düşüncelere sahip olduğu söylenebilir. 
Tablo 10. Katılımcıların Yaş ve Şehirdeki İkamet Sürelerine Göre Serbest Zaman Faaliyetlerine Yönelik Düşüncelerinin Karşılaştırılması (Kruskal-Wallis H Testi)

\begin{tabular}{|c|c|c|c|c|}
\hline Yaş & $\mathbf{n}$ & $\bar{x}$ & Chi-Square & $\mathbf{P}$ \\
\hline 25 yaş ve altı & 96 & 244,69 & \multirow{6}{*}{16,042} & \multirow{6}{*}{$0,007^{*}$} \\
\hline 26-30 yaş & 70 & 240,49 & & \\
\hline 31-35 yaş & 77 & 213,64 & & \\
\hline $36-40$ yaş & 59 & 190,90 & & \\
\hline $41-45$ yaş & 50 & 182,09 & & \\
\hline 46 yaş ve üstü & 77 & 196,01 & & \\
\hline Eğitim Durumu & $\mathbf{n}$ & $\bar{x}$ & Chi-Square & $\mathbf{P}$ \\
\hline İlköğretim & 51 & 204,61 & \multirow{5}{*}{4,681} & \multirow{5}{*}{0,322} \\
\hline Ortaöğretim & 116 & 204,63 & & \\
\hline Önlisans & 82 & 238,07 & & \\
\hline Lisans & 141 & 218,07 & & \\
\hline Lisansüstü & 39 & 199,85 & & \\
\hline İkamet Süresi & $\mathbf{n}$ & $\bar{x}$ & Chi-Square & $\mathbf{P}$ \\
\hline 1 Yıldan Az & 28 & 230,46 & \multirow{5}{*}{1,756} & \multirow{5}{*}{0,781} \\
\hline $1-5 Y_{11}$ & 83 & 218,58 & & \\
\hline 6-10 Y1l & 47 & 223,65 & & \\
\hline 11-15 Y 11 & 60 & 222,72 & & \\
\hline 16 Yil ve Üstü & 211 & 207,42 & & \\
\hline
\end{tabular}

Katılımcıların yaşları itibariyle serbest zaman faaliyetlerine yönelik düşünceleri değerlendirildiğinde; yaş grupları arasında anlamlı farklılık olduğu görülmektedir. Tablo 9'a göre serbest zaman faaliyeti ile yaş grupları arasındaki farklılıkla $\left(X^{2}=16,042 ; p<0,05\right)$ ilgili olarak 25 yaş ve altı ile 26-30 yaşında olanların diğer yaş grubundaki kişilere göre daha olumlu düşüncelere sahip oldukları söylenebilir. Bu durum gençlerin serbest zaman faaliyetlerine katılma konusunda daha istekli oldukları ve olgun yaştakilerle kıyaslandığında serbest zaman faaliyetlerine zaman ayırdıkları şeklinde yorumlanabilir. Zira olgun yaştaki bireylerin iş ve aile sorumluluklarının fazla olması serbest zaman faaliyetlerine katılmalarındaki en önemli engeller olabilir. Oysaki aile sorumlulukları az olan genç bireylerin kendileri için ayırabilecekleri daha çok zamanları bulunmaktadır. Bununla birlikte, serbest zaman faaliyetine ilişkin katılımcıların düşüncelerinin ikamet süresine göre $\left(X^{2}=1,756 ; p>0,05\right)$ bir farklılık göstermediği tespit edilmiştir. 
Tablo 10: Katılımcıların Meslek ve Aylık Gelir Durumlarına Göre Serbest Zaman Faaliyetlerine Yönelik Düşüncelerinin Karşılaştırılması (Kruskal-Wallis H Testi)

\begin{tabular}{|c|c|c|c|c|}
\hline Meslek & $\mathbf{n}$ & $\bar{x}$ & Chi-Square & $\mathbf{P}$ \\
\hline Memur & 114 & 193,00 & \multirow{8}{*}{10,677} & \multirow{8}{*}{0,153} \\
\hline Esnaf & 68 & 225,08 & & \\
\hline İşçi & 95 & 218,04 & & \\
\hline Emekli & 20 & 177,53 & & \\
\hline Öğrenci & 63 & 242,52 & & \\
\hline Yönetici & 19 & 244,05 & & \\
\hline Ev Hanımı & 27 & 202,44 & & \\
\hline Profesyonel işler & 23 & 229,63 & & \\
\hline Gelir Durumu & $\mathbf{n}$ & $\bar{x}$ & Chi-Square & $\mathbf{P}$ \\
\hline 1000 TL ve altı & 128 & 225,11 & \multirow{5}{*}{2,387} & \multirow{5}{*}{0,665} \\
\hline $1001-2000$ & 127 & 206,13 & & \\
\hline $2001-3000$ & 88 & 216,27 & & \\
\hline $3001-4000$ & 39 & 225,03 & & \\
\hline 4001 TL ve üzeri & 47 & 200,76 & & \\
\hline
\end{tabular}

Katılımcıların meslek ve aylık gelir durumlarına göre serbest zaman faaliyetlerine ilişkin düşünceleri değerlendirildiğinde meslekleri $\left(X^{2}=10,677 ; p>0,153\right)$ arasında ve aylık gelir durumları $\left(X^{2}=2,387 ; p>0,05\right)$ arasında farklılık belirlenememiştir. Serbest zaman faaliyetlerine ilişkin düşüncelerin ortalamaları incelendiğinde; en düşük düzeyde düşünceye sahip olanların emekliler ve en yüksek düzeyde düşünceye sahip olanların ise yöneticiler olduğu görülmektedir. Ayrıca aylık gelir durumu ile ilgili olarak katılımcılardan 1000 TL ve altı ile 3001-4000 TL arasında geliri olanların diğer gelir gruplarından daha olumlu düşündükleri söylenebilir.

\section{SONUÇ}

Sanayileşme ve küreselleşme süreçleriyle ortaya çıkıp şekillenen "serbest zaman" kavramı insan hayatının önemli bir parçasını oluşturmaktadır. Çalışma yaşamı dışında kalan zamanlarda yapılan etkinlikler kişilerin dinlenmesi, eğlenmesi ve rahatlamasını sağlayarak bireyin çalışma yaşamı için gerekli olan enerjiyi depolanmasina neden olmaktadır.

Çalışmadan elde edilen bulgular, bireylerin Safranbolu'da serbest zaman etkinliklerine yeterince katılamadıklarını göstermektedir. Bireylerin serbest zaman etkinliğine katılamama nedenleri, kişilerin faaliyetleri birlikte gerçekleştirebilecekleri arkadaşlarının olmaması, Safranbolu'da yapılacak faaliyetlerin yetersiz olması ve serbest zaman değerlendirme alışkanlığının olmamasıdır. Serbest zaman faaliyetlerinin yarısı evde yarısı ile açık alanda gerçekleştirilmektedir. Bu sonuç, Yeniçeri ve arkadaşlarının (2002) Muğla'da yaptıkları araştırmada bireylerin serbest zamanlarını evde ve açık kırsal alanlarda gerçekleştirdikleri sonuçları ile tutarlıdır. 
Safranbolu halkı serbest zaman faaliyetlerine bir saatten az zaman ayırmaktadır. Bu faaliyetler ağırlıklı olarak arkadaşlarla sonrasında ise eş ve çocuklarla geçirilmektedir. Bu durum arkadaşların serbest zamanın değerlendirilmesinde önemli rol oynadığını göstermektedir.

Safranbolu halkının serbest zamanlarını aile ile TV seyrederek, dinlenerek, gezmeye giderek, müzik dinleyerek genelde pasif aktivitelerle geçirdikleri görülmektedir. Bu faaliyetler arasında ev içi aktiviteler ilk sırayı almaktadır. Sonuçlar, Kurar ve Baltacı'nın (2014) Alanya halkının serbest zamanlarını piknik yaparak ve arkadaş ziyaretleri gerçekleştirerek geçirdikleri sonuçları ile tutarlı değildir.

Çalışmada Safranbolu halkının meslek, aylık gelir, cinsiyet, eğitim durumu, ikamet süresi gibi demografik değişkenlerinin serbest zaman faaliyetlerine katılmada anlamlı bir farklılık yaratmadığı sonucuna ulaşılmıştır. Bununla birlikte literatürdeki çalışmalarda serbest zaman faaliyetlerine katılmanın demografik değişkenlere göre anlamlı farklılık gösterdiğine dair sonuçlara ulaşılmıştır. Örneğin; Alanya'dan serbest zaman etkinliklerine katılanların çoğu erkektir (Kurar ve Baltacı, 2014). Kara ve arkadaşları (2011) çalışmalarında serbest zaman değerlendirme alışkanlıklarında cinsiyetler açısından anlamlı farklılıklar olduğu sonucuna varmışlardır.

Çalışmada serbest zaman faaliyetlerine katılmada medeni duruma göre farklılık olduğu; bekârların serbest zaman faaliyetlerine katılma konusunda evlilere göre daha olumlu düşüncelere sahip oldukları saptanmıştır. Ayrıca serbest zaman etkinliklerine katılmada yaş önemli bir değişkendir. Çalışmada 26-30 yaş ve 25 yaşın altında olan bireylerin yukarı yaştaki kişilere göre serbest zaman faaliyetlerine katılma konusunda daha olumlu düşüncelere sahip oldukları saptanmıştır. Ancak Arslan'ın (2014) çalışmasında serbest zaman faaliyetleri ile yaş arasında anlamlı bir ilişki olduğu, katılımcıların yaşları arttıkça amaçlı faaliyetlere katılma oranının arttığı saptanmıştır.

Çalışmadan elde edilen bulgular Safranbolu'da serbest zaman etkinliklerinin yeterli olmadığını ve bu etkinliklerin sayı ve niteliğinin arttırılması gerektiğini göstermektedir. Bu bağlamda Safranbolu halkının katılabileceği farklı serbest zaman faaliyeti seçeneklerinin geliştirilmesi gerekmektedir. Serbest zamanın yaşam kalitesini arttıran bir faktör olarak önemli olduğu vurgulanarak yaşamlarını daha kaliteli ve verimli geçirmeleri için halkın bilinçlenmesi sağlanmalıdır.

\section{KAYNAKÇA}

Abadan, N. (1961) Üniversite Öğrencilerinin Serbest Zaman Faaliyetleri, Ankara: A.Ü. Siyasal Bilgiler Fakültesi Yayınları. No:135-177.

Altunay, B. R. (2015).Ankara İli Keçiören İlçesindeki İlköğretim Okullarında Görev Yapan Öğretmenlerin Boş Zaman Etkinliklerine Katılım Motivasyonu, Türkiye Cumhuriyeti Ankara Üniversitesi Sağlık Bilimleri Enstitüsü, Ankara: Yayınlanmamış Yüksek Lisans Tezi.

Arslan, H. (2014).Üniversite Öğrencilerinin Boş Zaman Değerlendirme Tercihleri: Çankırı Karatekin Üniversitesi Örneği, Dumlupinar Üniversitesi Sosyal Bilimler Dergisi, (40): 193208. 
Bayer, M. Z. (1974) “Memleketimizde Tabiatı Koruma ve Rekreasyon”, Çalışma ve Çalışma Dışı Zamanın Planlanması Semineri, Ankara: ODTÜ.

Bodur, F. (1988). Anadolu Üniversitesi İktisadi ve İdari Bilimler Fakültesi Öğrencilerinin Boş Zamanlarını Değerlendirme Eğilimleri, Anadolu Üniversitesi Sosyal Bilimler Enstitüsü, Eskişehir: Yayınlanmamış Yüksek Lisans Tezi.

Dağlı, B. (2013). Ç.Ü. Kozan Meslek Yüksekokulu Öğrencilerinin Boş Zamanlarını Değerlendirme Eğilimlerinin Saptanması, Okan Üniversitesi Sosyal Bilimler Enstitüsü Türkçe İşletme Anabilim Dalı, Adana: Yayınlanmamış Yüksek Lisans Tezi.

Demirel, M. ve Harmandar, D. (2009). Üniversite Öğrencilerinin Rekreasyonel Etkinliklere Katılımlarında Engel Oluşturabilecek Faktörlerin Belirlenmesi, Uluslararası İnsan Bilimleri Dergisi, 6. (1): 838-846.

Ergin, G. (1974) “Boş Zamanları Değerlendirme Eğitimi ve Planlaması ", Çalışma ve Çalışma Dışı Zamanın Planlanması Semineri. Ankara: ODTÜ.

Göral, Ş. (2013). İnternet Ortamında Geçirilen Boş Zamanın Üniversite Öğrencilerinin Mutluluk Ve Yaşam Doyum Değerlerine Etkisi, Gazi Üniversitesi Sağlık Bilimleri Enstitüsü Beden Eğitimi ve Spor Anabilim Dalı Spor Yönetim Bilimleri, Ankara: Yayınlanmamış Yüksek Lisans Tezi.

Gülbahçe, Ö. (1996). Boş Zamanları Değerlendirme Alışkanlıkları: Türkiye Örneği, Atatürk Üniversitesi Sosyal Bilimler Enstitüsü Eğitim Bilimleri Anabilim Dalı, Erzurum: Yayınlanmamış Yüksek Lisans Tezi

Kara, A., İzci, E. ve Murathan, F. (2011). Beden Eğitimi Öğretmenlerinin Serbest Zamanlarını Değerlendirme Alışkanlıkları ve Öğrenmeye İlişkin Tutumları, e-Journal of New World Sciences Academy, 6, (1): 958-987.

Köybaşı, N. (2006). Boş Zaman Sosyolojisi ve Boş Zamanları Değerlendirme Aracı Olarak Dinlence Turizmi ve Kültür Turizmine Katılan Yerli Turistlerin Karşılaştırmalı Sosyolojik Analizi, Eskişehir Anadolu Üniversitesi Sosyal Bilimler Enstitüsü Turizm Ve Otel İşletmeciliği Anabilim Dalı, Eskişehir: Yayınlanmamış Yüksek Lisans Tezi.

Kurar, İ., ve Baltacı, F. (2014). Halkın Boş Zaman Değerlendirme Alışkanlıkları: Alanya Örneği, International Journal of Science Culture and Sport, 39-52.

Metin, T. C., Kesici, M. ve Kodaş, D. (2013). Rekreasyon Olgusuna Akademisyenlerin Yaklaşımları, Journal of Yasar University, 30, (8): 5021-5048.

Öksüz, E. (2012). Yüksek Öğrenim Kredi Ve Yurtlar Kurumu İle Özel Yurtlarda İkamet Eden Öğrencilerin Boş Zaman Faaliyetlerinin Değerlendirilmesi (Balıkesir İli Örneği), Balıkesir Üniversitesi Sosyal Bilimler Enstitüsü Beden Eğitimi ve Spor Ana Bilim Dalı, Balıkesir: Yayınlanmamış Yüksek Lisans Tezi.

Özgören, F. (2007). Boş Zaman Pazarlaması ve Müzecilikte Bir Uygulama, Marmara Üniversitesi Sosyal Bilimler Enstitüsü İşletme Anabilim Dalı Üretim Yönetimi Ve Pazarlama Bilim Dalı, İstanbul: Yayınlanmamış Yüksek Lisans Tezi.

Özşaker, M. (2012). Gençlerin Serbest Zaman Aktivitelerine Katılamama Nedenleri Üzerine Bir İnceleme, Selçuk Üniversitesi Beden Ĕ̆itimi ve Spor Bilim Dergisi, 14, (1): 126-131.

Pala, A. (2012). Beden Eğitimi ve Spor Öğretmenlerinin Boş Zaman Değerlendirme Alışkanlıklarının ve Mesleki Doyumlarının Tespiti ve İncelenmesi (İstanbul - Pendik 
Örneği), Sakarya Üniversitesi Eğitim Bilimleri Enstitüsü Beden Eğitimi ve Spor Anabilim Dalı, Sakarya: Yayınlanmamış Yüksek Lisans Tezi.

Sabbağ, Ç. ve Aksoy, E. (2011). Üniversite Öğrencileri ve Çalışanların Boş Zaman Etkinlikleri: Adıyaman Örneği, Mehmet Akif Ersoy Üniversitesi Sosyal Bilimler Enstitüsü Dergisi, 3, (4): 10-23.

Sarıbaş, R. (2010). Eğirdir Bahçe Kültürleri Araştırma Enstitüsü Çalışanlarının Rekreasyonel Eğilim ve Taleplerinin Belirlenmesi Üzerine Bir Çalışma, Selçuk Üniversitesi Fen Bilimleri Enstitüsü Peyzaj Mimarlı̆̆ı Anabilim Dalı, Konya: Yayınlanmamış Yüksek Lisans Tezi.

Şentürk, Ü. (2012).Tüketim Toplumu Bağlamında Boş Zamanların Kurumsallaştırdığı Bir Mekân: Alışveriş Merkezleri (AVM), Pamukkale Üniversitesi Sosyal Bilimler Enstitüsü Dergisi,(13): 63 -77.

Yaşar, N. N. (2015). Türkiye'deki Bireylerin Kişilik Özellikleri, Facebook Kullanımları ve Boş Zaman Aktiveleri, İstanbul Teknik Üniversitesi Fen Bilimleri Enstitüsü Endüstri Mühendisliği Anabilim Dalı Endüstri Mühendisliği Programı, İstanbul: Yayınlanmamış Yüksek Lisans Tezi.

Yazıcıoğlu, M. (2010). Boş Zaman Yönetimi ve Rekreatif Faaliyetler: Memur Emeklilerinin Rekreatif Faaliyetlerinin Analizine İlişkin Bir Uygulama, Beykent Üniversitesi Sosyal Bilimler Enstitüsü İşletme Yönetimi Anabilim Dalı İşletme Yönetimi Bilim Dalı, İstanbul: Yayınlanmamış Yüksek Lisans Tezi.

Yeniçeri, M., Coşkun, B. ve Özkan, H. (2002). Muğla İl Merkezindeki Memurların Boş Zaman Değerlendirme Eğilimlerinin Belirlenmesi Üzerine Bir Araştırma, Muğla Üniversitesi SBE Dergisi, (7).

Yetim, G. (2014). Boş Zaman İlgileniminin Boş Zaman Tatmini ve Sadakati Üzerine Etkisi: Eskişehir'deki Fitnes Merkezleri Üzerine Araştırma, Anadolu Üniversitesi Sağlık Bilimleri Enstitüsü Beden Eğitimi ve Spor Anabilim Dalı Eskişehir: Yayınlanmamış Yüksek Lisans Tezi. 